\title{
ORIGINAL
}

\section{Biodegradation of 2-Sulfonatofatty Acid Methyl Ester ( $\alpha-\mathrm{SFMe})$.II. Biodegradation Pathways of $\alpha-\mathrm{SFMe}$}

\author{
Mitsuteru MAsUdA*, Hiroshi OdAKE*, Kazuaki MiURA*, \\ Keiko ITO**, Kaoru YAMADA**, and Kenkichi OBA*** \\ * Human Safety Evaluation Center, Lion Corporation \\ (100, Tajima, Odawara-shi, Kanagawa-ken, ₹256) \\ ** Analytical Research Center, Lion Corporation \\ (13-12, Hirai 7 Chome, Edogawa-ku, Tokyo, ₹132) \\ *** Research \& Development Headquarters, Lion Corporation \\ (13-12, Hirai 7 Chome, Edogawa-ku, Tokyo, ₹132)
}

The biodegradation pathways of $\alpha$-SFMe were determined based on changes in the chemical structure of $\mathrm{C}_{14}-\alpha-$ SFMe by IR, NMR and HPLC analyses in the MITI test.

Microbial attack on the surfactant structure was initiated by $\omega$-oxidation to form a carboxyl group and continued with $\beta$-oxidation, causing the removal of two carbons at a time, to form a temporary intermediate, monomethyl $\alpha$-sulfosuccinate. Degradation subsequently occurred by desulfonation.

\section{Introduction}

2-Sulfonatofatty acid methyl esters $(\alpha-$ $\mathrm{SFMe}$ ) have been successfully applied to new compact heavy duty laundry detergents as a main surfactant having the excellent detergent properties.

$\alpha$-SFMe also has splendid advantages in the sense of environmental acceptability, i.e., in addition to its high biodegradability, smaller amounts are needed to obtain satisfactory detergency, thus lowering the organic load in wastes discharged to the natural environment ${ }^{1)},{ }^{2)}$.

In our previous study ${ }^{3)}$, the primary and ultimate biodegradation of $\alpha$-SFMe was assessed by methylene blue analysis and dissolved organic carbon (DOC) removal in the shake culture method [Japanese Industrial Standards (JIS) K 3363) and in a river die-away test. Its ultimate biodegradation was also based on oxygen consumption using the Japanese MITI test. The results indicated that the biodegradation of $\alpha-\mathrm{SFMe}$

Corresponding author : Mitsuteru MASUDA starts quickly, and then proceeds rapidly to ultimate degradation at sewage treatment plant and in natural river water.

In this study, the biodegradation pathways of $\alpha$-SFMe were assessed by following the changes in the chemical structure of $\mathrm{C}_{14}-\alpha-\mathrm{SFMe}$ by IR, NMR and HPLC analyses in the MITI test $\left.{ }^{4)}, 5\right)$.

\section{Materials and methods}

\subsection{Test compound}

Sodium 2 - sulfonatofatty acid methyl ester $\left(\mathrm{C}_{14}-\alpha-\mathrm{SFMe}\right.$, mol. wt. : 344 , purity : 99.4 $\%)$. It was produced by sulfonation and neutralization of distilled methyl tetradecanoate. The product was purified by the conventional procedure for use.

\subsection{Activated sludge}

Activated sludge was obtained from a municipal sewage treatment plant in Sakawa, Odawara. The sludge was cultured in a semicontinuous activated sludge system ${ }^{6}$ ) for use.

\subsection{Biodegradation test}

Biodegradation tests were performed with 
$\mathrm{C}_{14}-\alpha-\mathrm{SFMe}$ using the MITI test $\left.{ }^{4)}, 5\right)$ to investigate the biodegradation pathways of $\alpha$-SFMe.

Thirty $\mathrm{mg} / \mathrm{L}$ of activated sludge in the basal medium was prepared and $50 \mathrm{mg} / \mathrm{L}$ of $\mathrm{C}_{14}-\alpha-\mathrm{SFMe}$, as a sole carbon source, was added to it. Biochemical oxygen demand (BOD) was measured using an automatic electrolytic meter (Ohkura Electric Co., LTD. Coulometer), and biodegradability was calculated as the ratio of BOD to the theoretical oxygen demand (TOD). The ratio (BOD/TOD) indicates the degree of ultimate degradation.

The changes in chemical structure of $\mathrm{C}_{14}$ $\alpha-\mathrm{SFMe}$ in the course of its biodegradation were assessed by IR, NMR and HPLC analyses.

\subsection{Analytical method}

IR : The cultured media at the biodegradation stages of 7 and $18 \%$ (BOD/TOD) were freeze-dried and their $\mathrm{C}_{14}-\alpha-\mathrm{SFMe}$ biodegradation residues were extracted with $95 \%$ ethyl alcohol. The IR absorption spectra of the extracts and parent material, which were mixed with $\mathrm{KBr}$ and compressed into solids, were measured using a Fourier transform IR spectrometer (Horiba, FT-200).

NMR : The cultured media at the biodegradation stages of 12,35 and $65 \%$ (BOD/ TOD) were freeze-dried and their $\mathrm{C}_{14}-\alpha-$ $\mathrm{SFMe}$ biodegradation residues were extracted with $95 \%$ ethyl alcohol. The extracts (10 30 mg) were dissolved in deuterium oxide or deuterated acetic acid. The NMR spectra were then measured using a JEOL GSX-400 NMR spectrometer. NMR conditions are shown in Table-1.

HPLC : The cultured media at the biodegradation stages of 47,71 and $79 \%$ (BOD/ TOD) were centrifuged at $3000 \mathrm{rpm}$ to remove microorganisms and the supernatants were then applied to a HPLC detector (Model IC-500, Ion-chromato Analyzer, Yokogawa Analytical Systems Co.) under the following conditions to detect the inorganic sulfate released during the course of $\mathrm{C}_{14}-\alpha$ -SFMe biodegradation. Measured inorganic sulfate was corrected by subtraction of result in parallel unfed control run.

Column

: SAX 1-205

(4.6 mm I.D. $\times 200 \mathrm{~mm} \mathrm{L.)}$

Precolumn

: PAX 1-035

(4.6 mm I.D. $\times 30 \mathrm{~mm} \mathrm{L.)}$

Suppressor : Cation exchange membrane tube

Scavenger : $15 \mathrm{mM} \mathrm{H}_{2} \mathrm{SO}_{4}, 2 \mathrm{~mL} / \mathrm{min}$

Temperature : $45^{\circ} \mathrm{C}$

Injection volume

: $100 \mu \mathrm{L}$ (with ODS pretreatment cartridge)

Mobile phase : $4 \mathrm{mM} \mathrm{Na}_{2} \mathrm{CO}_{3} / 4 \mathrm{mM}$ $\mathrm{NaHCO}_{3}, 2 \mathrm{~mL} / \mathrm{min}$

\section{Results and discussion}

IR analysis - $\omega^{-}$and $\beta$-oxidation of alkyl chain-

Fig. -1 shows the IR absorption spectra of the parent $\mathrm{C}_{14}-\alpha-\mathrm{SFMe}$ and its biodegradation residues at the $\mathrm{BOD}$ removal (BOD/ TOD) of 7 and $18 \%$.

The changes in the absorptions at bands around 2930, 1727 and $1045 \mathrm{~cm}^{-1}$ came from the methylene, carbonyl and sulfonate groups, respectively. They were examined before and after biodegradation of the $\mathrm{C}_{14}$ $\alpha$-SFMe. The absorption decreased in the $2930 \mathrm{~cm}^{-1}$ methylene band as the biodegradation proceeded whereas there was no change in the $1727 \mathrm{~cm}^{-1}$ carbonyl band or $1045 \mathrm{~cm}^{-1}$ sulfonate band. This indicates that the main metabolic pathway of $\alpha-\mathrm{SFMe}$ begins with attack on the terminal of the alkyl chain to form a carboxyl group ( $\omega-$ oxidation), followed by $\beta$-oxidation of the

Table-1 NMR operation conditions.

\begin{tabular}{r|c|c|c|l}
\hline & Pulse flip angle & Pulse repetition time & Accumulated times & \multicolumn{1}{c}{ Mode } \\
\hline${ }^{1} \mathrm{H}-\mathrm{NMR}$ & $30^{\circ}$ & $5 \mathrm{~s}$ & 16 & Normal \\
${ }^{13} \mathrm{C}-\mathrm{NMR}$ & $30^{\circ}$ & $2 \mathrm{~s}$ & $5,000 \sim 10,000$ & Complete decoupling \\
\hline
\end{tabular}

TMS or TSP $-\mathrm{d}_{4}$ was used as the internal standard for chemical shifts. 


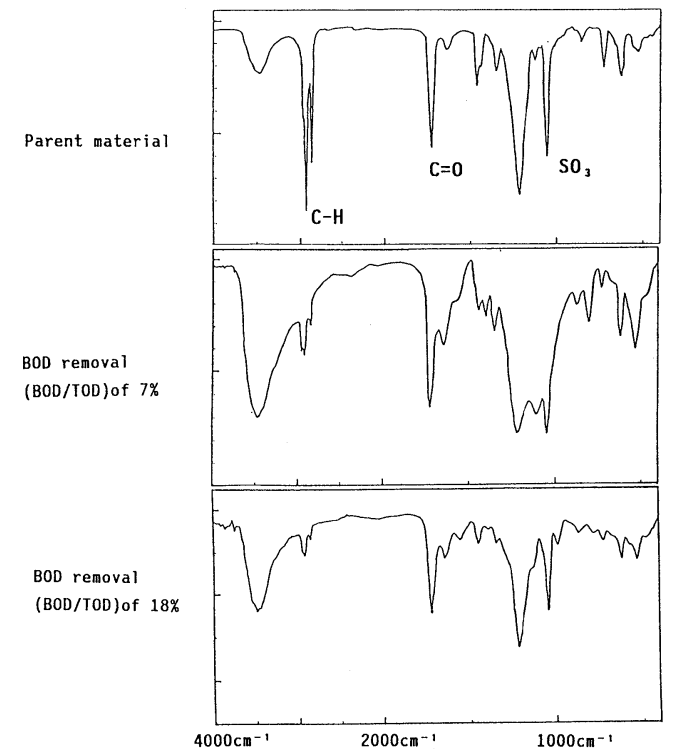

Fig. -1 IR absorption spectra of $\alpha-$ SFMe and its biodegradation residues.

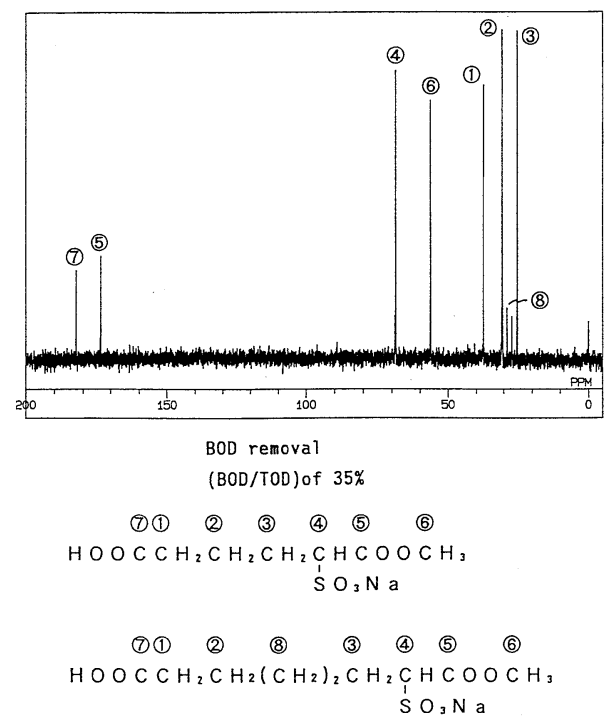

Fig. $-2 \quad{ }^{13} \mathrm{C}-\mathrm{NMR}$ spectra of biodegradation residues of $\alpha$-SFMe.

chain via the mechanism also used in the biodegradation of aliphatic hydrocarbons. NMR analysis_Chemical structure of biodegradation products

Fig. -2 and -3 show the NMR spectra of the biodegradation residues of $\mathrm{C}_{14}-\alpha-\mathrm{SFMe}$ at the BOD removal of 12,35 and $65 \%$.
The terminal carboxylated longer chain $\alpha$ -SFMe appeared during the early biodegradation (Fig. -2 and 3), then the chain had been shortened to six or four carbons at the time when the biodegradation reached $65 \%$ BOD removal (Fig. - -3), indicating that the microbial attack on the surfactant structure started with $\omega$-oxidation to form a carboxyl group and continued with $\beta$-oxidation, removing two carbons at a time. Monomethyl $\alpha$-sulfosuccinate $\left(\mathrm{HOOCCH}{ }_{2} \mathrm{CH}\left(\mathrm{SO}_{3} \mathrm{Na}\right)\right.$ $\mathrm{COOCH}_{3}$ ] was a major intermediate resulting from the $\beta$-oxidation at the BOD removal of $65 \%$. The next step of $\beta$-oxidation beyond the $\mathrm{C}_{4}$ acid, monomethyl $\alpha$-sulfosuccinate, would be attack on carbon number 2 $(\alpha)$ preparatory to scission of the $2-3$ bond. Evidently this attack is more difficult than the previous steps due to proximity to the sulfonate group, and the succinate temporarily accumulated in the medium until the bacteria learned how to degrade it. The subsequent attack might be through the sulfonate group as mentioned below, and the intermediate would then disappear.

This temporary accumulation tends to occur under such conditions as the one in this study where the test compound was exposed with a comparatively higher concentration to a sort of batch activated sludge. This differs from the practical conditions like the continuous activated sludge found in the sewage treatment plants. However, the varied bacterial talents needed for the ultimate biodegradation are maintained by being acclimatized, and many different pathways and path sequences may be simultaneously operating in the continuous systems. Actually, Steber ${ }^{7)}$ and Gerike ${ }^{8)}$ demonstrated the high primary and ultimate biodegradability of $\alpha$-SFMe in the continuous activated sludge systems and Gerike concluded that the degradation is apparently free of any residues.

As for the effects of the surfactant concentration on the biodegradation, the degradation proceeded more smoothly and reached higher levels in shorter periods as the dosed $\alpha$-SFMe concentration decreased, as shown in our previous study ${ }^{3)}$. 

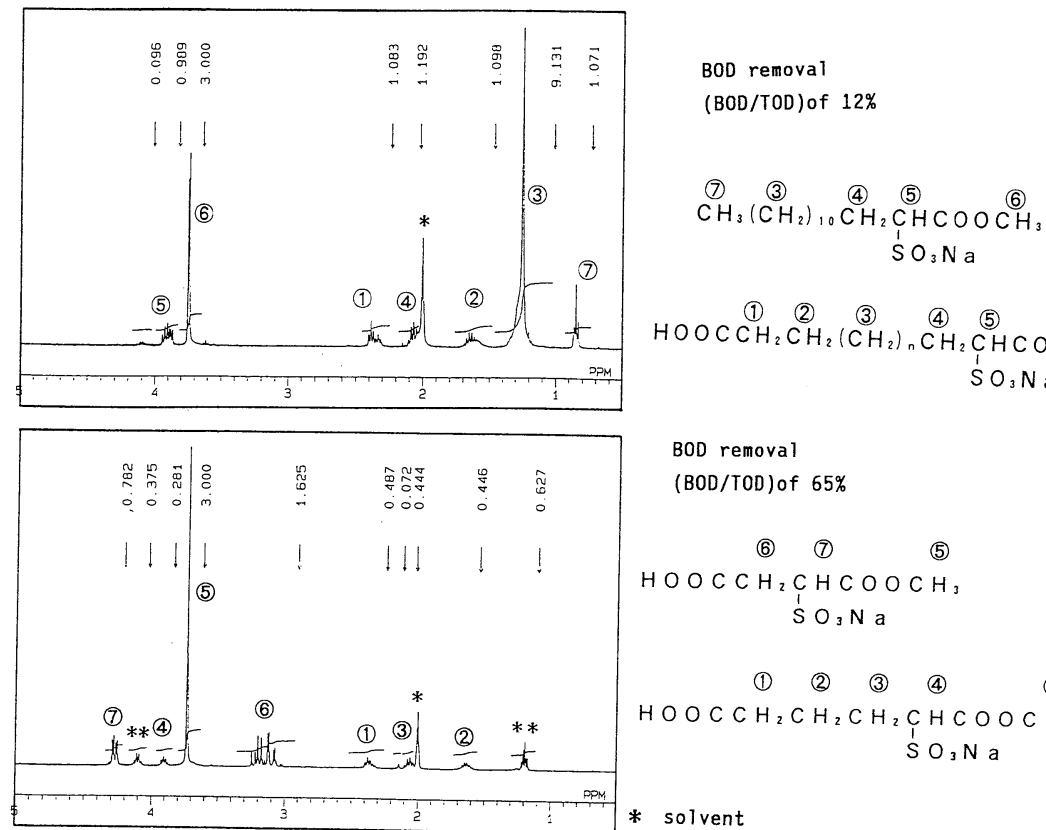

BOD removal

(BOD/TOD) of $65 \%$

(6) (7) (5)

$\mathrm{HOOCCH} \mathrm{CHCOOCH}_{3}$ $\mathrm{SO}_{3} \mathrm{Na}$

$81 \%$

(1) (2) (3) (4) (5)

$\mathrm{HOOCCH} \mathrm{CH}_{2} \mathrm{CH}_{2} \underset{1}{\mathrm{CHCOOCH}} 19 \%$

* solvent

**ethyl ester(formed by ethanol extraction)

Fig. $-3 \quad{ }^{1} \mathrm{H}-\mathrm{NMR}$ spectra of biodegradation residues of $\alpha-\mathrm{SFMe}$.

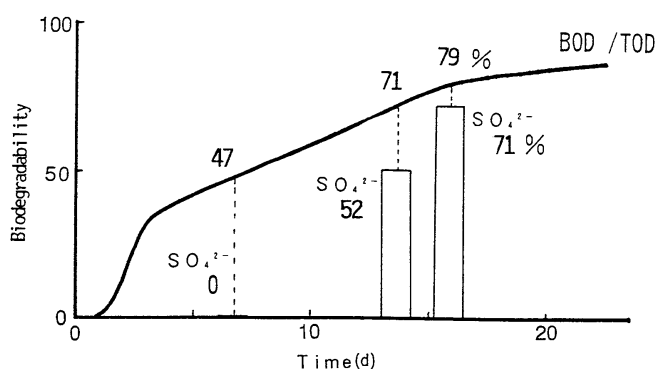

Fig. $-4 \mathrm{SO}_{4}{ }^{2-}$ ion release during biodegradation of $\alpha-\mathrm{SFMe}$.

HPLC analysis-Biodesulfonation-

Fig. -4 shows the inorganic sulfate release at different stages of the $\mathrm{C}_{14}-\alpha-\mathrm{SFMe}$ biodegradation in BOD removal.

No inorganic sulfate was found at a BOD removal of $47 \%$. Inorganic sulfate started to appear in the medium at about halfway through the biodegradation, then rose rapidly to reach about $50 \%$ and $70 \%$ of the total at BOD removal of about $70 \%$ and 80 $\%$, respectively. The inorganic sulfate release paralleled the oxygen uptake except for an initial delay, suggesting that the inorganic sulfate release was one of the later steps in the $\alpha$-SFMe biodegradation. These results and NMR analyses (Fig. -3 ) indicate

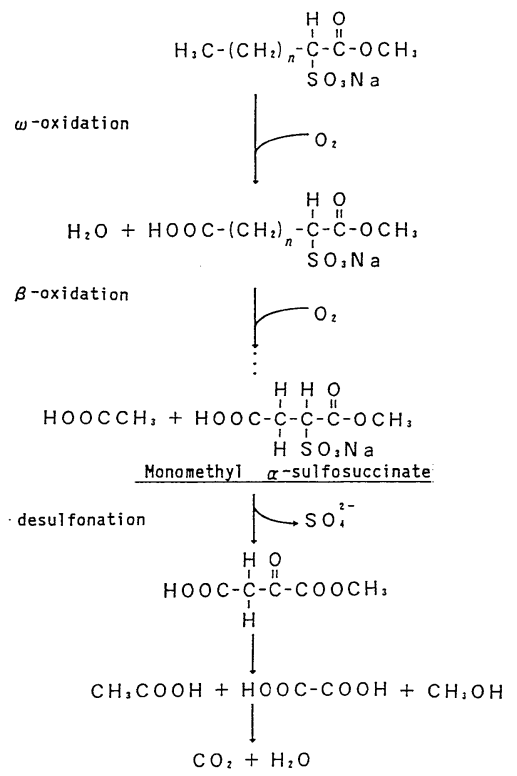

Fig. -5 Biodegradation pathway of $\alpha$-SFMe.

that $\alpha$-SFMe was biodegraded to form a temporary intermediate, monomethyl $\alpha$-sulfosuccinate, then the degradation proceeded further by desulfonation. Desulfonation is assumed to take place prior to the scission of the methyl ester bond of the monomethyl $\alpha$-sulfosuccinate since this bond is chemi- 
cally very stable on account of the $\alpha$-sulfosubstitution $^{9)}$. So, the desulfonation step is rate limiting in the biodegradation process of $\alpha$-SFMe.

\section{Conclusions}

From the results of the experiments described above, the estimated biodegradation pathways of $\alpha$-SFMe are as follows :

The microbial attack on the surfactant structure started with $\omega$-oxidation to form a carboxyl group and continued with $\beta$-oxidation, removing two carbons at a time, to form a temporary intermediate, monomethyl $\alpha$-sulfosuccinate, then the degradation proceeded further by desulfonation (Fig.-5). The desulfonation was assumed to take place prior to the scission of the methyl ester bond of the monomethyl $\alpha$-sulfosuccinate.

(Received May 31, 1993)

\section{References}

1) T. Satsuki, K. Umehara and Y. Yoneyama, J. Am. Oil Chem. Soc., 69, 672 (1992).

2) T. Satsuki, INFORM, 3, 1099 (1992).

3) M. Masuda et al., J. Jpn. Oil Chem. Soc. (YUKAGAKU), 42, 643 (1993).

4) Law Concerning Examination and Regulation of Manufacture, etc. of Chemical Substances (Japan).

5) OECD Guidelines for Testing of Chemicals,
301 C, OECD Publication Office, Paris(1981).

6) SDA, Biodegradation Subcommittee, J. Am. Oil Chem. Soc., 42, 986 (1965).

7) J. Steber and P. Wierich, Tenside, 26, 406 (1989).

8) P. Gerike and W. Jasiak, Tenside, 23, 300 (1986).

9) W. Stein and H. Baumann, J. Am. Oil Chem. Soc., 52, 323 (1975).

\section{2ースルホネート脂肪酸メチルエステル \\ $(\alpha-\mathrm{SFMe})$ の生分解性（第 2 報） $\alpha-\mathrm{SFMe}$ の生分解経路}

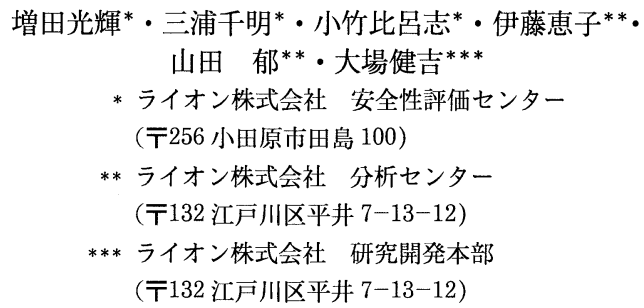

生分解 (MITI 法) 過程における $\mathrm{C}_{14}-\alpha-\mathrm{SFMe}$ の化 学構造の変化を IR, NMR 及び HPLC 分析で追跡し, $\alpha-\mathrm{SFMe}$ の生分解経路を検討した。

その結果つぎのことが示唆された。微生物による $\alpha$ -SFMe の分解は, アルキル基末端におけるカルボキシ ル基の形成 $(\omega$-酸化) に始まり, 炭素数が 2 個ずつは ずれる $\beta$-酸化が続き，一時的に，分解中間体である $\alpha-$ スルホコハク酸モノメチルが生成する。この分解中間体 は脱硫酸化後さらに分解する。

（連絡者：増田光輝） 